\title{
Comparison between the decellularized bovine pericardium and the conventional bovine pericardium used in the manufacture of cardiac bioprostheses
}

Comparação entre o pericárdio bovino decelularizado e o pericárdio bovino convencional utilizado na confecção de biopróteses valvares cardíacas

Jean Newton Lima COSTA, Pablo Maria Alberto POMERANTZEFF, Domingo Marcolino BRAILE, Vladimir Aparecido RAMIREZ, Gilberto GOISSIS, Noedir Antônio Groppo STOLF

RBCCV 44205-724

Abstract

Introduction: In this paper, our objective was to compare the decellularized and conventional pericardium mechanical resistance and also its capability of inducing inflammatory response in an animal experimental model.

Methods: In order to study these properties, we divided the pericardia into two groups: Group I - pericardium conventionally treated with GTA and Group II - pericardium previously decellularized and then treated with GTA in the conventional way. After the chemical treatment, Group II samples were histologically evaluated to confirm the efficacy of the decellularization process. Then, only for the analysis of mechanical resistance, pericardia were divided in: Groups 1 (conventional pericardia with criteria of approval), 2 (conventional pericardial with criteria of rejection) and 3 (decellularized pericardia). The capacity of inducing inflammatory response was tested in a rat experimental model using 50 Wistar rats, in which rats of each group received patches of the pericardia in the abdomen. Our third step of analysis was to manufacture three decellularized pericardium bioprostheses which were submitted to hydrodynamic evaluation together with a conventional bioprosthesis test.

Results: The histological analysis showed complete decellularization. Mechanical resistance gave statistical differences in the "tension of rupture" and "tenacity index" tests. We found no difference in the inflammatory activity in the animal model. Hydrodynamic performance was similar and all prostheses reached 150 million cycles. The final histological analysis assessed the standard microscopic pattern and no rupture or abnormal fragmentation was caused by mechanical stress.

Conclusion: The decellularization technique maintains the physical resistance of the pericardium when compared with the conventionally prepared pericardium. And also, there was no difference in both groups regarding to inflammatory response studied in the animal model.

Descriptors: Heart valve prosthesis. Bioprosthesis. Pericarduim. Comparative study.

Instituto do Coração - Incor/ FMUSP - São Paulo/SP

Braile Biomédica - São José do Rio Preto/SP

Instituto de Química de São Carlos - USP/ São Carlos/SP

Faculdade de Ciências da Saúde - University de Brasília - Brasília/DF

Correspondence address:

Jean Newton Lima Costa

SQN 303 B1. D Apt 606. Asa Norte. CEP: 70833-00 Brasília/DF

Phones: 61 - 328-1596 / 9961-8837/ 245-4041

E-mail: jeanluc15@terra.com.br 


\section{Resumo}

Objetivo: Neste estudo, tivemos como objetivo comparar a resistência mecânica do pericárdio decelularizado com o pericárdio convencional, assim como avaliar sua capacidade de induzir resposta inflamatória em modelo experimental com ratos.

Método: Dividimos os pericárdios em: Grupo I - pericárdio submetido a tratamento convencional com glutaraldeído e Grupo II - pericárdio submetido a tratamento de decelularização, previamente ao tratamento convencional. Após o processamento químico, as amostras do Grupo II foram histologicamente avaliadas para confirmar a eficácia da decelularização. A seguir, apenas para análise da resistência mecânica por testes de tração e de desnaturação térmica, os pericárdios foram divididos em: grupo 1 (pericárdio convencional com critérios de aprovação), grupo 2 (pericárdio convencional com critérios de reprovação) e grupo 3 (pericárdio decelularizado). A capacidade de induzir resposta inflamatória foi avaliada em estudo experimental em 50 ratos Wistar, os quais foram submetidos a implante subcutâneo de fragmentos dos pericárdios. Nossa terceira etapa de avaliação consistiu em confeccionar três biopróteses com o pericárdio

\section{INTRODUCTION}

The treatment of valvar heart disease has been one of the big challenges of Cardiac Surgery over the last few decades. Native valve replacement by prostheses has been the most important advance in the treatment of patients with this disease, even though this is not without complications [1].

Mechanical prostheses offer satisfactory hemodynamic function and excellent durability over the long term, but as they are thrombogenic, they require permanent anticoagulation, which increases the risk of bleeding [2-5]. Bioprostheses present a hemodynamic profile even better, however, both replacement valves made from porcine aortic valves and bovine pericardium fixed in glutaraldehyde induce activation of the immune system [6,7], triggering an inflammatory reaction $[7,8]$ that leads to infiltration of the collagen matrix, rupture of the collagen-elastin network and calcification [9-11]. These events invariably result in valvar dysfunction and the necessity of reoperation [2-5].

Faced with this, there has been much study aiming at finding a strategy that creates a biocompatible prosthesis which is resistant over the long term. Existing evidence suggests that decellularization of biomaterials makes the tissue less antigenic, reducing the inflammatory response and causing less tissue degeneration [12-14]. However, until now, the decellularization process of bovine pericardium decelularizado e que foram submetidas à avaliação hidrodinâmica, juntamente com uma bioprótese convencional de teste.

Resultados: A análise histológica inicial demonstrou decelularização completa. A resistência mecânica mostrou diferença significativa com relação às variáveis "tensão de ruptura" e "índice de tenacidade". Não encontramos diferença quanto à atividade inflamatória em modelo experimental com ratos. $O$ desempenho hidrodinâmico foi semelhante e todas biopróteses atingiram a marca de $\mathbf{1 5 0}$ milhões de ciclos. A avaliação histológica ao fim da ciclagem mostrou padrão microscópico habitual, não havendo ruptura ou fragmentação anormal induzida por estresse mecânico.

Conclusão: A decelularização mantém a resistência física do pericárdio, além de não induzir resposta inflamatória diferente daquela habitualmente encontrada no pericárdio convencional.

Descritores:

Prótese das valvas cardíacas. Bioprótese. Pericárdio. Estudo comparativo.

has not been studied with the objective of producing heart bioprostheses.

In this work, the physical proprieties of decellularized bovine pericardium were compared to conventional bovine pericardium. Also, its capacity of inducing inflammatory response in an experimental in vivo model and the accelerated durability of prosthesis produced from this material were investigated.

\section{METHOD}

\section{Procurement of the biological material}

Samples of bovine pericardium were obtained in abattoirs immediately after the slaughter of under 37-month-old animals.

The material was then prepared in plastic containers

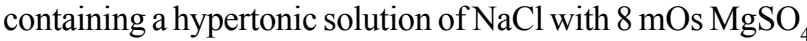
buffered at $\mathrm{pH} 7.4$ using a $0.13-\mathrm{M}$ phosphate buffer and transported to the laboratory at $4^{\circ} \mathrm{C}$ within a maximum 4 hours [15].

In the laboratory, the pericardia were washed an isotonic $0.9 \% \mathrm{NaCl}$ solution and all the fat and adherences were removed.

\section{Decellularization process}

The bovine pericardium was placed on a support to be submitted to the decellularization treatment. It was 
treated at $20^{\circ} \mathrm{C}$ for 24 hours in an alkaline solution $(3 \mathrm{~mL} /$ g) containing $(\mathrm{v} / \mathrm{v}) 6 \%$ sulphoxide dimethyl, salts (chloride and sulfate), alkaline bases $\left(1.19 \mathrm{M} \mathrm{K}^{+}\right.$and $1.74 \mathrm{M}$ $\left.\mathrm{Na}^{+}\right)$and alkaline earth $\left(0.86 \mathrm{M} \mathrm{Ca}^{2+}\right)$. The resulting material was placed in a solution of $\mathrm{Na}_{2} \mathrm{SO}_{4}, \mathrm{NaCl}, \mathrm{KCl}$ and $\mathrm{CaSO}_{4}$ ( $96 \mathrm{~mL}$ of solution per gram of tissue) for a period of 6 hours and the excess of residual salts was removed by successive washings with $3 \%$ boric acid, distillated water and $0.3 \%$ EDTA at $\mathrm{pH} 11$, followed of stabilization of the material in a $0.14 \mathrm{~mol}^{-1}$ phosphate buffer at $\mathrm{pH}$ 7.4. After this procedure the pieces of pericardium were washed $(3 \mathrm{x}$ for 15 minutes in distilled water) [16].

\section{Reticulation with glutaraldehyde}

The materials were then treated in $0.05 \%$ glutaraldehyde in a $0.14 \mathrm{molL}^{-1}$ phosphate buffer at $\mathrm{pH} 7.4$ for 15 minutes, followed by a glycine borate buffer solution. After this the pericardium was washed six times in a $0.14 \mathrm{molL}^{-1}$ phosphate buffer at $\mathrm{pH} 7.4$ and sent to Braile Biomédica for processing. All this procedure was made in the Chemistry School of USP, São Carlos at the temperature of $5^{\circ} \mathrm{C}[16]$.

At Braile Biomédica, the pericardium was washed in an isotonic $0.9 \% \mathrm{NaCl}$ solution. Then, it was submitted to fixing in purified $0.5 \%$ glutaraldehyde in a phosphate buffer 0.13 $\mathrm{M}$ at $\mathrm{pH}$ 7.4. Subsequently, the samples were washed for six times of 15 minutes each in a phosphate buffer and treated with $0.005 \mathrm{M}$ borate buffer solution / $0.025 \mathrm{M}$ glutamic acid adjusting the $\mathrm{pH}$ alkaline using $0.1 \mathrm{~N} \mathrm{NaOH}$ and left for 24 hours at room temperature.

Completing the tanning period, the pericardium was preserved in a solution of $4 \%$ formaldehyde with a $0.2 \mathrm{M}$ acetate buffer at $\mathrm{pH} 5.4$ for three days when it was submitted to quality control [15].

\section{Quality control}

\section{Macroscopic anatomy}

All the pericardial samples was analyzed in respect to the macroscopic aspect using a polarized light. Those with abnormal infiltrations or thicknesses or any type of defect were discarded [15].

\section{Histologic examination}

Microscopic evaluation by random sampling of different pericardial fragments was performed with the objective of establishing the histologic standard in the studied samples, even considering that this procedure is not routine in the manufacture and preparation of heart bioprostheses. This study also served to demonstrate the effectiveness of decellularization of the samples.

The histologic study by evaluation of microscopic anatomy utilizes the normal methods of embedding in paraffin wax, using
3- to 5-micron sections and staining using hematoxylin-Eosin (HE), Gomori's trichrome (TG) and Verhoeff stain (VH).

\section{Mechanical resistance of the pericardium}

This evaluation consisted in static traction tests (rupture tension, stretching and tenacity index) and a shrinking test. Standardized samples of $6 \times 20 \mathrm{~mm}$, fixed using tweezers on special apparatuses, were utilized $[17,18]$.

Just for this evaluation, the pericardium was divided into three groups with 10 fragments in each. Group 1 conventional bovine pericardium suitable for the production of bioprostheses: Group 2 - conventional pericardium rejected for the manufacture of bioprostheses and Group 3 - decellularized bovine pericardium.

\section{Hydrodynamic assessment}

The fatigue or accelerated durability were tested in a Shelhigh FTS 300 fatigue tester - USA, with four evaluation chambers (Figure 1) and analysis of the hydrodynamic performance was tested in an automatic pulse duplicator system of Shelhigh model V. 4.0 - USA (Figure 2). Three decellularized pericardial bioprostheses (mitral ${ }^{\circ} 29$ ) and one conventional bovine pericardial bioprosthesis (mitral, $\mathrm{n}^{\circ} 29$ - Braile Biomédica) were placed in the fatigue tester for evaluation of mechanical wear. The test was interrupted at every $50 \times 10^{6}$ cycles to assess the hydrodynamic performance. The hydrodynamic profiles were assessed at zero, $50 \times 10^{6}, 100 \times 10^{6}$ and $150 \times 10^{6}$ of cycles.

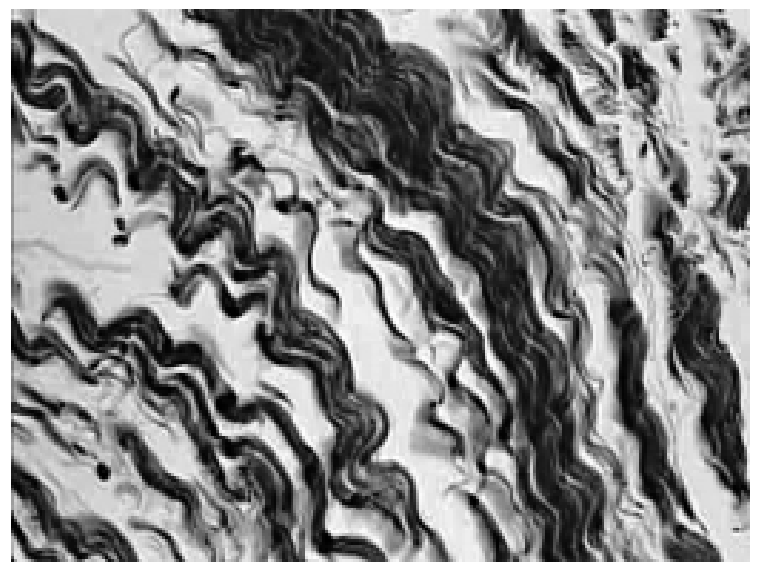

Fig. 1 - Fragment of bovine pericardium stained by HematoxylinEosin and visualized magnified at 400x. The preservation of normal undulation of collagen filament and absence of cellularity were evidenced. 


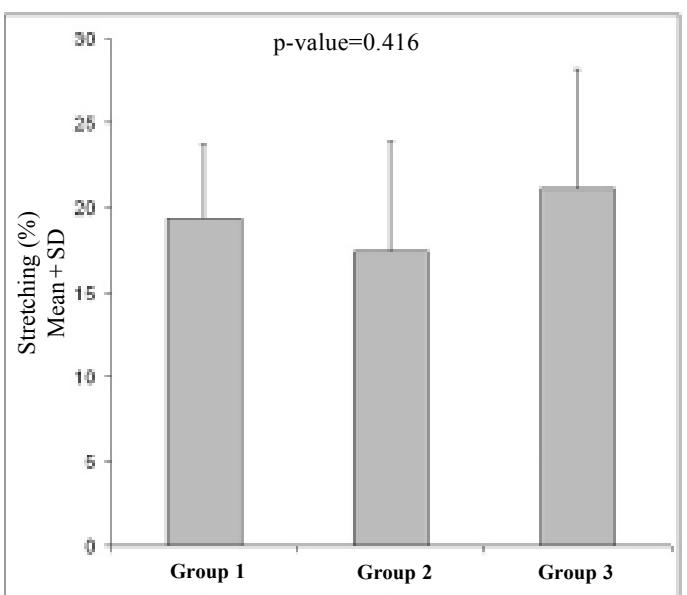

Fig. 2 - Histogram exhibiting the variations in stretching - there was no statistical difference among the four prostheses their basal $(\mathrm{B})$, medial $(\mathrm{M})$ and free $(\mathrm{F})$ regions were studied.

The fragments were embedded in paraffin and were stained using HE, TG and VH. They were classified using a score of from zero to three crosses for the characterization of cellularity and the filament pattern of the collagen and elastin in the tissues. Again a single observer evaluated the samples.

\section{Statistical analysis of the data}

The data was described as minimum and maximum values, median, mean and standard deviations.

The pericardial groups were compared by variance analysis and multiple comparisons were achieved using the Tukey test.

The studied animal model variables were evaluated using the Wilcoxon signed rank test for matched samples.

Comparisons of the hydrodynamic variables were achieved using variance analysis and the multiple comparisons by the Wald test.

A significance level of 0.05 was adopted for all comparisons.

\section{RESULTS}

\section{Histologic evaluation of the pericardium}

After procurement, treatment and conditioning of the bovine pericardial fragments, histologic evaluation was made to confirm the effectiveness of the decellularization process. An optical microscopic was utilized to define the absence of fragments and cellular remains in the treated pericardium and to characterize the fibrillation pattern of the collagen and elastin. The effectiveness of the decellularization process that removes the matrixes of fixed cells and the cellular remains which normally remain in the pericardium after fixing with glutaraldehyde was observed (Figure 1).

Also checks were made to see that the decellularization technique did not damage the fiber network of the collagen and elastin.

Evaluation of the mechanical resistance of pericardium

From the results of the comparative tests of the groups, it is possible to conclude that there are no significant differences between the groups in respect to the thickness, stretching and temperature variables, as illustrated in Figures 2 and 3. For this last variable, only Groups 1 and 3 was considered, as there were no values greater than zero for Group 2, making its inclusion in the inferential analysis impossible. Additionally, Group 1 presented mean values of rupture tension and tenacity index significantly greater that the other two groups (pvalue $<0.001)$ (Figures 4 and 5 ). 


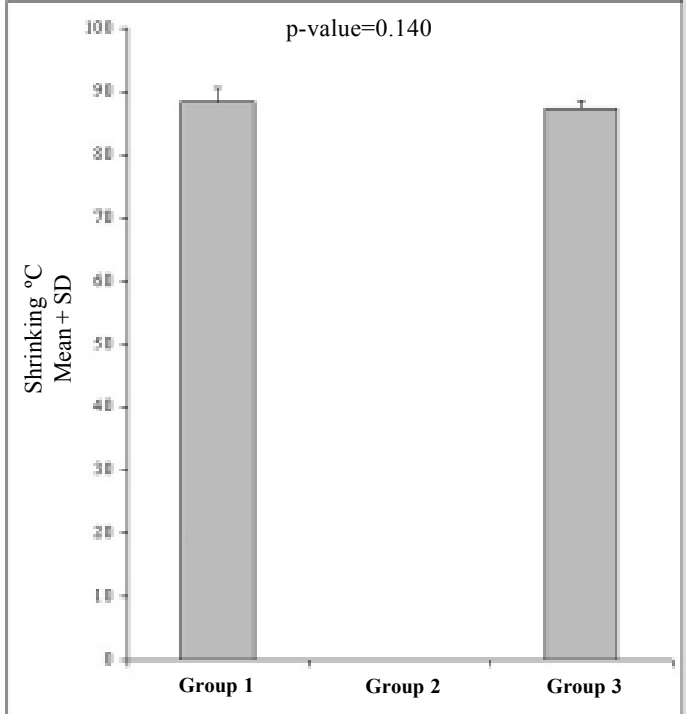

Fig. 3 - Histogram of shrinking temperature - there was no statistical difference between the Groups 1 and 3. Group 2 was not analysed

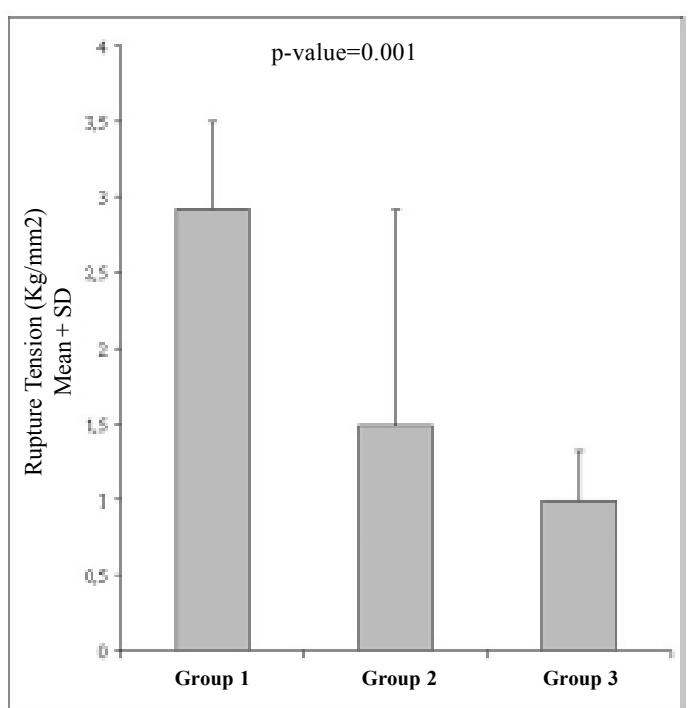

Fig. 4 - Histogram of the rupture tension there was a significant difference between Group 1 and the others

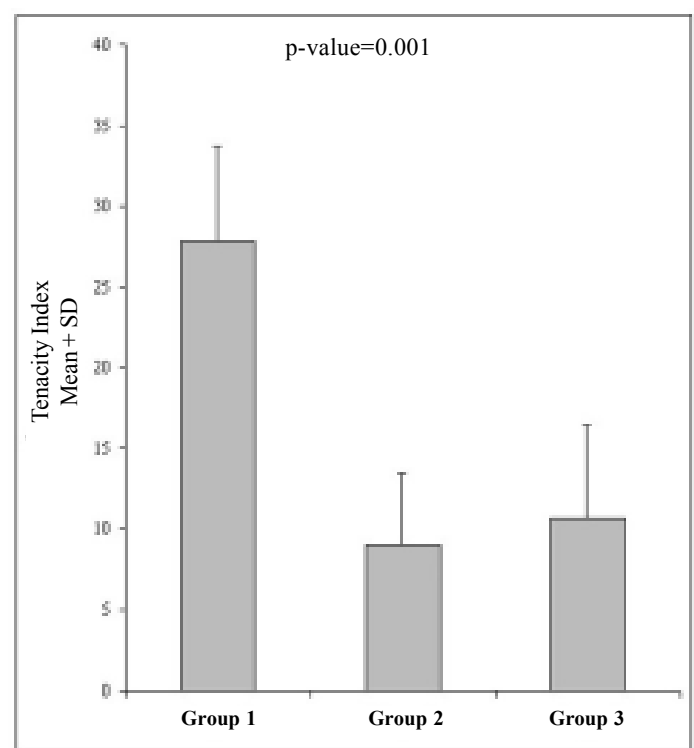

Fig. 5 - Histogram showing the variations among the tenacity index of the three groups - Group 1 demonstrated a statistically significant difference in respect to the other two groups which did not statistically differ between each other

Histologic evaluation in the animal experimental model From the results of the comparative tests of the groups, it is possible to conclude that there are no significant differences between the groups in respect to the granuloma and infiltration variables at any of the time intervals. The inferential analysis of calcification was not made as no values were different to zero.

\section{Hydrodynamic evaluation of the bioprostheses}

The global hemodynamic performance was statistically similar for all four bioprostheses studied. Statistical differences were found in relation to some analyzed measurements however, not one was seen as a difference of mechanical behavior between different prostheses and all the measurements remained within the recommended values recommended in the literature. It is important to stress that the statistical analysis for this evaluation was exploratory and it is not possible to extrapolate data (Figures 6 to 9). 


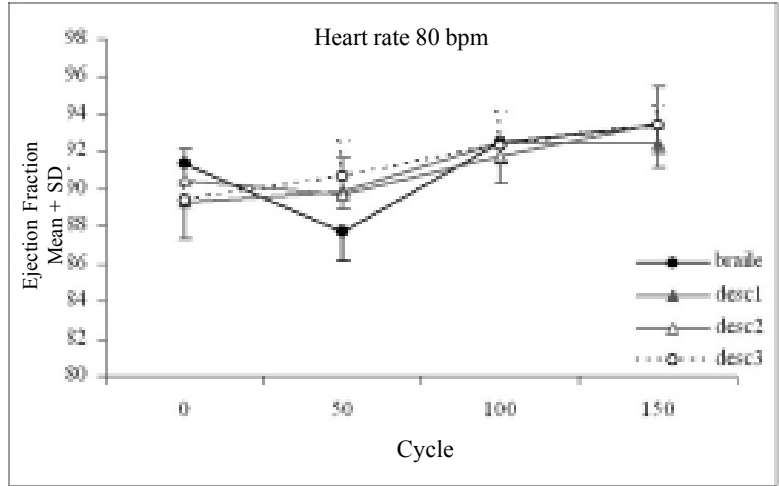

Fig. 6 - Variations in the Ejection Fractions of the four prostheses at $80 \mathrm{bpm}$

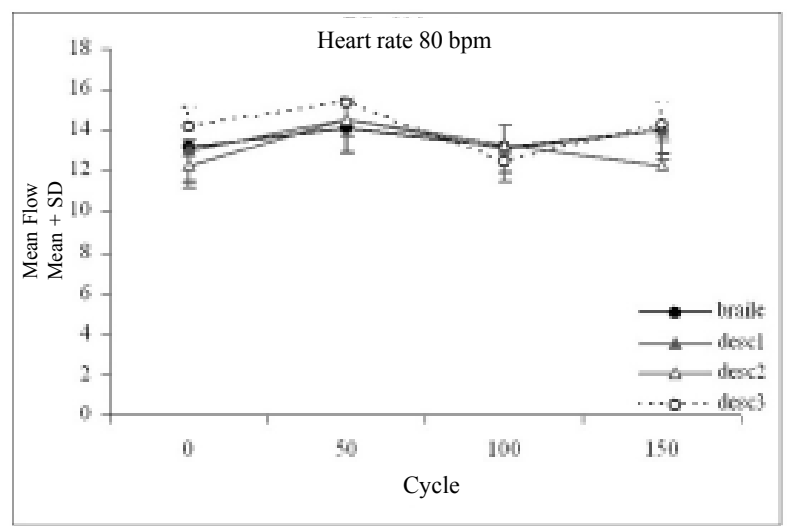

Fig. 7 - Variations in the mean transvalvar flows at $80 \mathrm{bpm}$

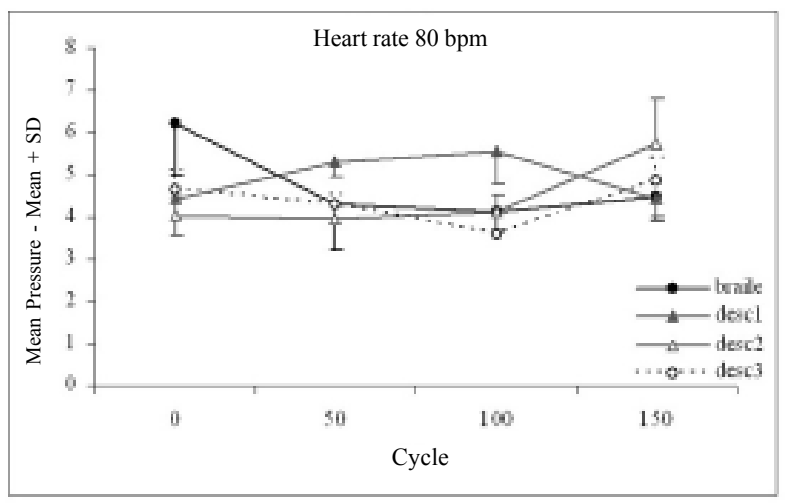

Fig. 8 - Variation in the mean transvalvar pressure in the four prostheses

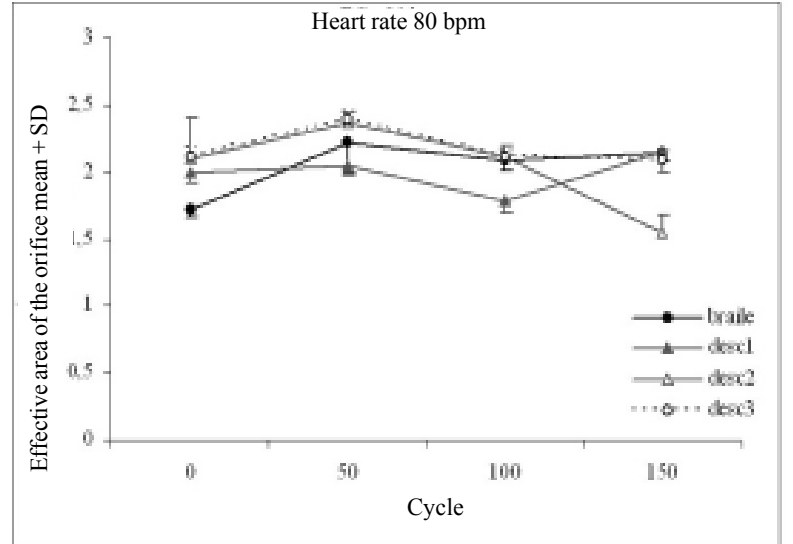

Fig. 9 - Effective area of the orifice that expresses the area that effectively is open during the valvar cycle

\section{Final histologic aspects of the prostheses}

The final histologic examination of the pericardium removed from the bioprostheses confirmed the decellularization of the study samples and demonstrated preservation of its viscoelastic characteristics with the absence of ruptures or fragmentation.

\section{DISCUSSION}

The implantation of valvar heart prostheses has been realized for almost half a century, but a prosthesis with satisfactory criteria of durability and biocompatibility has not been developed yet. The ideal graft should present adequate resistance, be able to tolerate long-term mechanical stress; have a hemodynamic profile comparable to native valves; be immunocompatible, not trigger the defense responses of the host; be resistant to degeneration by infiltration, rupture of the fibroelastic tissue and calcium deposition; have a capacity of maintain the vitality of the proteic collagen, elastin and glycoaminnoglycan network and present a low cost.

Of all factors currently considered as being responsible for prosthetic degeneration, by far, those which are the most important and are the most studied are calcification and the toxicity of glutaraldehyde [19-23]. Among the mechanisms involved in calcification, there is evidence that the presence of dead cells and cellular debris incompletely fixed by the treatment methods, work as calcification nuclei, permitting the deposition of calcium, sodium and magnesium phosphate and carbonate crystals [23]. In addiction, treatment with glutaraldehyde can work as a triggering factor for calcium deposition. It has already been demonstrated that high levels 

manufacture of cardiac bioprostheses

of glutaraldehyde incorporated in the biological tissue are related to a greater tendency of calcification in an experimental model with mice [24]. The chance relation between pre-treatment with glutaraldehyde and calcification was studied by NIMNI et al. [25], who demonstrated that the glutaraldehyde polymers and the free carbonylic residues in the collagen matrix provide an initial site for the deposition of calcium complexes.

Thus, several strategies have been evaluated with the objective of eliminating or minimizing tissue degeneration induced by these factors, in particular by using the decellularization technique. Detergents have been used, as described by COURTMANN et al. [26] and DOHMEN et al. [27]; enzymatic extraction by means of tripsin as described by STEINHOFF et al. [28], the Synergraft technique presented by O'BRIEN et al. [13]; and even cellular extraction utilized by GOISSIS et al. [16, 29] in the Institute of Chemistry of USP, São Carlos which was the method employed in this study.

In our study, complete decellularization was achieved. This was verified during the initial histological evaluation of the treated pericardium of which one fragment was removed for analysis. The same result was observed in the final histological examination of the pericardial bioprostheses in which three regions of each leaflet were tested. Other histological evaluations of decellularized bovine pericardium, which we did not include in this study, confirmed the efficacy of the method. Note that this result is not always obtained as was reported by SCHENKELAYLAND et al. [30] who described "almost complete" decellularization in porcine valves treated by enzymatic digestion using tripsin.

The collagen and elastin matrix was preserved. Significant fragmentation or rupture was not seen in any of evaluated specimens. Additionally, the final comparison of the pericardial bioprostheses of both groups did not demonstrate significant differences in the histologic pattern. It is important to note that the histologic evaluation has a subjective component, it depends on the assessment of an observer. Keeping this in mind, to minimize any possibility of difference in interpretation, all the samples were assessed by a single observer.

In relation to the static traction tests, we found very interesting results. The three groups of pericardium were compared as previously described. Group 2 (pericardium inappropriate for the manufacture of bioprosthesis) with the aim of assessing if the decellularized pericardial bovine had a physical behavior comparable to substandard pericardium, if it proved to be inferior to approved conventional pericardium.

The criterion "thickness" was similar among the three groups, with $n=0.117$. This is the first suggestion that the chemical process of decellularization did not affect the quality of the collagen or elastin matrix. This result opposes previous reports that showed alterations in the thickness of pericardium treated by other techniques as already mentioned.

The stretching defined as deformation suffered by the sample until rupturing gave similar results in all the three groups ( $p$-value $=0.416$ ). This data suggests that both the quality of treated pericardium was maintained and that its elasticity was not affected by treatment.

The rupture tension and the tenacity index proved to be superior for the good quality conventional bovine pericardium, with the decellularized pericardium comparable to the rejected conventional bovine pericardium. This data is conflicting keeping in mind that the thickness and the rupture tension has a linear correlation, that is, the greater the thickness of the material, the proportionally greater is the tension necessary to rupture it. However, we believe that this variation is due to removal of the cellular components that, even incompletely fixed, improve the resistance of the tissue, without affecting the thickness. This hypothesis is corroborated by the existent tenacity index. The tenacity is the energy necessary to rupture the tissue. This was seen to be better in Group I in relation to the other two groups and Groups II and III were similar.

Finally and more importantly, the shrinking temperature was similar for Groups I and III. This variable expresses the quality of the pericardium reticulation technique and its resistance after processing. Thus, even though the traction and tenacity were better in Group I, the final resistance of pericardia was not affected.

It is important to note that these physical tests are preliminary tests in the study of the quality of a biomaterial and of the prostheses manufactured from the material. The test results show us that the pericardium presents minimum criteria of resistance and so it is possible to proceed with the physical evaluation of the studied material with laboratorial hydrodynamic tests and hemodynamic tests in animals before continuing with the possibility of clinical application.

Concluding this part of the study, the capacity of causing inflammatory response and calcification in an experimental model in mice was evaluated.

In this material, the presence of inflammatory activity was identified and granulomatous formations were already seen in seven-day explants. Similar patterns were observed in the groups of sacrificed animals in the later periods. No vestiges of calcification were found in any explanted specimens of the two groups at any time interval. Although the finding of an absence of calcification in the control material was unexpected, Marina Maizato from the Heart Institution, FMUSP reported similar results in a comparative 

manufacture of cardiac bioprostheses

study between lyophilized bovine pericardium and conventional bovine pericardium (verbal communication).

In respect to the accelerated durability and hydrodynamic profile tests, we found similar performances among the four prostheses. We compared the three DBPC prostheses against one $\mathrm{PBC}$ control as suggested by national (NBR ISO 5840) and international norms (ANSI/AAMI/ISO 58401996) for heart bioprosthesis manufacture. The bioprostheses was accelerated to $60,70,80,90$ and $100 \mathrm{bpm}$ at each $50 \times 10^{6}$ cycles to assess the performance and the test was interrupted at $150 \times 10^{6}$ cycles. However, for a question of clarity, only the results at $80 \mathrm{bpm}$ (mean heart rate) are reported here. For the analyzed variables, there was no overall difference between the bioprostheses for any of the cycles and the graphically exhibited variations were randomly attributed. It is worthwhile noting that in our pilot project, we used two decellularized bovine pericardium prostheses that were submitted to accelerated durability for more than $300 \times 10^{6}$ cycles and that maintained their macro and microscopic structural integrity similar to the DBPC assessed here. Besides the resistance demonstrated, an evaluation of the performance shows us that the DBPC did not undergo alterations in the elasticity or in the movement of the leaflets, as well as maintained a good opening, which is illustrated by flow curves, the pressure and orificial opening. Thus, even though it is not possible to make any definitive affirmation about the quality of the DBPC, we consider the hydrodynamic study to be an initial exploratory evaluation whose preliminary results point to a promising area of research. In the future, these findings need of to be confirmed by experimentation using an animal model for an in vivo performance evaluation.

Finally, the evaluation of the leaflets removed from the bioprostheses confirmed the absence of cellularity in the DPBC samples and showed a normal pattern of collagen and elastin matrix without significant differences between the groups.

\section{CONCLUSIONS}

We evidenced significant differences between the conventional bovine pericardium and the decellularized bovine pericardium in relation to the physical resistance considering the rupture tension and tenacity index, however, there were no significant differences in relation to the thickness, stretching and the shrinking temperature.

The capacity of the decellularized pericardium to produce an in vivo inflammatory response did not present significant differences with respect to the conventional pericardium and the decellularized pericardium bioprostheses presented a similar hydrodynamic behavior to the conventional bovine pericardium bioprosthesis.
In light of the obtained results, even though there are some isolated discrepancies, we considered the performance of the two types of pericardium similar, both in the assessment of the tissue itself and the bioprostheses. This study is part of only one of the evaluation stages of new materials or new techniques to manufacture heart valvar prostheses. It is impossible to generalize or to extrapolate data about the decellularized bovine pericardium prosthesis just from these findings alone. Our findings verified the quality of the evaluated biomaterial and the comparable behavior of the two materials, which enable us to go to the next stage. This will consist of an in vivo experimental study in larger animals, for example in dogs, pigs or sheep, in which we will be able to analyze the behavior of the prostheses in contact with blood and in conditions closer to those seen in humans, even though these models are not ideal. However, this is an essential stage in the pre-clinical evaluation, without which it is not possible to continue to the final stage which is the study in anima nobili.

\section{BIBLIOGRAPHIC REFERENCES}

1. Rahimtoola SH. Lessons learned about the determinants of the results of valve surgery. Circulation. 1988;78(6):1503-7.

2. Blomfield P, Wheatley DJ, Prescott RJ, Miller HC. Twelveyear comparison of a Bjork-Shiley mechanical heart valve with porcine bioprostheses. New Engl J Med. 1991;324(9):573-9.

3. Hammermeister KE, Sethi GK, Henderson WG, Oprian C, Kim T, Rahimtoola S. A comparison of outcomes in men 11 years after heart-valve replacement with a mechanical valve or bioprosthesis. New Engl J Med. 1993;328(18):1289-96.

4. Hammermeister KE, Sethi GK, Henderson WG, Grover FL, Oprian C. Outcomes 15 years after valve replacement with a mechanical versus a bioprosthetic valve: final report of the Veterans Affairs randomized trial. J Am Coll Cardiol. 2000;36(4):1152-8.

5. Peterseim DS, Cen YY, Cheruvu S, Landolfo K, Bashore TM, Lowe JE et al. Long-term outcome after biologic versus mechanical aortic valve replacement in 841 patients. J Thorac Cardiovasc Surg. 1999;117(5):890-7.

6. Dahm M, Lyman WD, Schwell AB, Factor SM, Frater RW Immunogenicity of glutaraldehyde-tanned bovine pericardium. J Thorac Cardiovasc Surg. 1990;99(6):1082-90. 

manufacture of cardiac bioprostheses

7. Gong G, Seifter E, Lyman WD, Factor SM, Blau S, Frater RW. Bioprosthetic cardiac valve degeneration: role of inflammatory and immune reactions. J Heart Valve Dis. 1993;2(6):684-93.

8. Vyavahare NR, Jones PL, Hirsch D, Schoen FJ, Levy RJ. Prevention of glutaraldehyde-fixed bioprosthetic heart valve calcification by alcohol pretreatment: further mechanistic studies. J Heart Valve Dis. 2000;9(4):562-6.

9. Schoen FJ, Golomb G, Levy RJ. Calcification of bioprosthetic heart valves: a perspective on models. J Heart Valve Dis. 1992;1(1):110-4.

10. Pelletier LC, Carrier M, Leclerc Y, Lepage G, deGuise P, Dyrda I. Porcine versus pericardial bioprostheses: a comparison of late results in 1593 patients. Ann Thorac Surg. 1989;47(3):352-61.

11. Cunanan CM, Cabiling CM, Dinh TT, Shen SH, Tran-Hata P, Rutledge III JH et al. Tissue characterization and calcification potential of commercial bioprosthetic heart valves. Ann Thorac Surg. 2001;71(5 suppl.):S417-21.

12. Elkins RC, Dawson PE, Goldstein S, Walsh SP, Black KS Decellularized human valve allografts. Ann Thorac Surg. 2001;71(5 suppl.):S428-32.

13. O'Brien MF, Goldstein S, Walsh S, Black KS, Elkins R, Clarke D. The SynerGraft valve: a new acellular (nonglutaraldehydefixed) tissue heart valve for autologous recellularization first experimental studies before clinical implantation. Semin Thorac Cardiovasc Surg. 1999;11(4 suppl 1):194-200.

14. Grauss RW, Hazekamp MG, Vleit S, Gittenberger-de-Groot AC, DeRuiter MC. Decellularization of rat aortic valve allografts reduces leaflet destruction and extracellular matrix remodeling. J Thorac Cardiovasc Surg. 2003;126(6):2003-10.

15. Braile DM. Prótese valvular de pericárdio bovino: desenvolvimento e aplicação clínica em posição mitral [Tese]. São Paulo: Escola Paulista de Medicina; São Paulo,1990.

16. Rosa FP, Lia RC, Souza KO, Goissis G, Marcantonio Jr. E. Tissue response to polyanionic collagen: elastin matrices implanted in rat calvaria. Biomaterials. 2003:24(2):207-12.

17. Braile DM. (Braile Biomédica - São José do Rio Preto/SP e Instituto de Física e Química - USP de São Carlos/SP). Programa de pesquisa e desenvolvimento de biomateriais a base de colágeno e poliuretana. São José do Rio Preto: Braile Biomédica;1993. Relatório II.

18. Braile DM. (Braile Biomédica - São José do Rio Preto/SP e Instituto de Física e Química - USP de São Carlos/SP). Programa de pesquisa e desenvolvimento de biomateriais a base de colágeno e poliuretana. São José do Rio Preto: Braile Biomédica;1994. Relatório III.
19. Meuris B, Phillips R, Moore MA, Flameng W. Porcine stentless bioprostheses: prevention of aortic wall calcification by dyemediated photo-oxidation. Artif Organs. 2003;27(6):537-43.

20. Maizato MJ, Higa OZ, Mathor MB, Camillo MA, Spencer PJ, Pitombo RN et al. Glutaraldehyde-treated bovine pericardium: effects of lyophilization on cytotoxicity and residual aldehydes. Artif Organs. 2003;27(8):692-4.

21. Grimm M, Eybl E, Grabennwöger M, Griesmacher A, Losert U, Böck P et al. Biocompatibility of aldehyde-fixed bovine pericardium: an in vitro and in vivo approach toward. $\mathrm{J}$ Thorac Cardiovasc Surg. 1991;102(2):195-201.

22. Grabenwöger M, Fitzal F, Gross C, Hutschala D, Bock P, Brucke $P$ et al. Different modes of degeneration in autologous and heterologous heart valve prostheses. J Heart Valve Dis. 2000;9(1):104-11.

23. Schoen FJ. Future directions in tissue heart valves: impact of recent insights from biology and pathology. J Heart Valve Dis. 1999;8(4):350-8.

24. Grabenwöger M, Sider J, Fitzal F, Zelenka C, Windberger U, Grimm $\mathrm{M}$ et al. Impact of glutaraldehyde on calcification of pericardial bioprosthetic heart valve material. Ann Thorac Surg. 1996;62(3):772-7.

25. Nimni ME, Bernick S, Cheung DT, Ertl DC, Nishimoto SK, Paule WJ et al. Biochemical differences between dystrophic calcification of cross-linked collagen implants and mineralization during bone induction. Calcif Tissue Int. 1988;42(5):313-20.

26. Courtman DW, Pereira CA, Kashef V, McComb D, Lee JM, Wilson GJ. Development of a pericardial acellular matrix biomaterial: biochemical and mechanical effects of cell extraction. J Biomed Mater Res. 1994;28(6):655-66.

27. Dohmen PM, Ozaki S, Yperman J, Flameng W, Konertz W. Lack of calcification of tissue engineered heart valves in juvenile sheep. Semin Thorac Cardiovasc Surg. 2001;13(4 suppl 1):93-8.

28. Steinhoff G, Stock U, Karim N, Mertsching H, Timke A, Meliss $\mathrm{RR}$ et al. Tissue engineering of pulmonary heart valves on allogenic acellular matrix conduits: in vivo restoration of valve tissue. Circulation. 2000;102(19 suppl. 3):III50-5.

29. Rocha LB, Goissis G, Rossi MA. Biocompatibility of anionic collagen matrix as scaffold for bone healing. Biomaterials. 2002;23(2):449-56.

30. Schenke-Layland K, Opitz F, Gross M, Döring C, Halbhuber KJ, Schirrmeister F et al. Complete dynamic repopulation of decellularized heart valves by application of defined physical signals: an in vitro study. Cardiovasc Res. 2003;60(3):497-509. 